\title{
Locomotor Skills: Traditional Games In The Fundamental Of Physical Activities
}

\author{
Fajar Awang Irawan ${ }^{1, *}$, Sutaryono ${ }^{2}$, Dhias Fajar Widya Permana ${ }^{3}$, Long-Ren Chuang ${ }^{4}$, Yuwono ${ }^{5}$ \\ 1,2,3,5 Universitas Negeri Semarang, Indonesia \\ ${ }^{4}$ Chinese Culture University, Taiwan (R.O.C) \\ *fajarawang@mail.unnes.ac.id
}

\begin{abstract}
Motor coordination will be hampered if the stimulation of children's movement development tends to be neglected. This will have an impact on the child's movement skills. The purpose of this study was to determine traditional games in basic physical activities using locomotor skills. This study uses Classroom Action Research (PTK) which aims to see how much increase in the application of traditional games. The research was conducted at Madrasah Ibtidaiyah Lerep Ungaran Barat and this study used male students aged 7-9 years. There were 18 children who followed and participated in traditional games in this study. Only 8 children scored 44-62 and 10 children scored 63-81, so there were still some children who had not developed according to expectations in cycle I. Basic locomotor skills in cycle II obtained the developing category according to expectations. totaled 3 children and Very Good Development as many as 15 children. Activities carried out by children can increase stimulation and can develop movement skills to improve children's motor skills. The data on basic locomotor motion skills in pre-cycle is $33 \%$ in the Undeveloped category. In the first cycle, 45\% was found in the Start Developing category and in the second cycle it was $83 \%$ in the Very Developed category. This study found that traditional games are suitable for the development of fundamental locomotor skills. Future research can add to children's physical fitness activities that can monitor their increase in physical abilities.
\end{abstract}

Keywords: locomotor skills; physical activity; traditional games

\section{Keterampilan Lokomotor: Permainan Tradisional Dalam Fundamental Aktivitas Fisik}

\begin{abstract}
Abstrak
Koordinasi motorik akan terhambat jika stimulasi perkembangan gerak anak cenderung diabaikan. Hal demikian akan berdampak pada keterampilan gerak anak. Tujuan dari penelitian ini adalah untuk mengetahui permainan tradisional dalam kegiatan fisik dasar dengan menggunakan keterampilan lokomotor. Penelitian ini menggunakan Penelitian Tindakan Kelas (PTK) yang bertujuan untuk melihat seberapa besar peningkatan penerapan permainan tradisional. Penelitian dilakukan di Madrasah Ibtidaiyah Lerep Ungaran Barat dan penelitian ini menggunakan siswa laki-laki berusia 7-9 tahun. Ada 18 anak yang mengikuti dan mengikuti permainan tradisional dalam penelitian ini. Hanya 8 anak yang memperoleh nilai 44-62 dan 10 anak yang berada pada nilai 63-81, sehingga masih terdapat sebagian anak yang belum berkembang sesuai harapan pada siklus I. Keterampilan dasar lokomotor pada siklus II didapatkan kategori berkembang sesuai harapan. berjumlah 3 orang anak dan Perkembangan Sangat Baik sebanyak 15 orang anak. Kegiatan yang dilakukan anak dapat meningkatkan gerak rangsangan dan dapat mengembangkan keterampilan gerak untuk meningkatkan keterampilan motorik anak. Data pada keterampilan gerak dasar lokomotor prasiklus sebesar 33\% pada kategori Belum Berkembang. Siklus I didapatkan 45\% pada kategori Mulai Berkembang dan pada siklus II sebesar $83 \%$ pada kategori Sangat Berkembang. Studi ini menemukan bahwa permainan tradisional sesuai untuk pengembangan keterampilan lokomotor yang mendasar. Penelitian selanjutnya dapat menambahkan aktivitas kebugaran jasmani anak yang dapat memantau peningkatan kemampuan fisiknya.
\end{abstract}

Kata Kunci: keterampilan lokomotor; aktivitas fisik; permainan tradisional 


\section{INTRODUCTION}

Development of early childhood aimed at children from birth to age six years. This guidance was carried out through giving responses for physical education to help the growth and development of movement in the body and the soul (Kurniawan, 2018). Physical activity supports the children to have readiness to set a higher level of education (Wijaya Kuswanto \& Dinda Pratiwi, 2020). Games used in children are games that can stimulate creativity and fun. There is no element of coercion and play and its naturally simple. Motor development is one of the activities that can develop motor aspects optimally and can stimulate children's brain development. The development of the motoric aspects aims to introduce and train gross and fine movements, improve the ability to manage, control and coordinate body movements, and improve body skills and a healthy lifestyle as conveyed by Apriliani, Yasbiati, \& Elan, (2020) so that it can support skills and physical growth.

Early childhood education was a media in organizing activities that focus on laying the basic foundation towards the physical development of children, especially in fine and gross motor coordination, intelligence, socio-emotional, language and communication. The growth of early childhood education was adjusted to the stages of development that every child goes through at his age (Safrudin, 2017; Wijaya Kuswanto \& Dinda Pratiwi, 2020). Children have enormous potential to optimize all aspects of their development, including the development of motor skills as the elements of maturity and control of the body movements (Septi, 2015). Motor skills were divided into two parts, there were gross motor and fine motor. Gross motor was an activity using large muscles which includes locomotor, non-locomotor and manipulative motion. Fine motor meant the ability of preschool children to move using smooth muscles. The basic of locomotor skills were the movement which certain body parts to moving. Basic locomotor movement skills include walking, running, jumping and hoping (Wijaya Kuswanto \& Dinda Pratiwi, 2020; Wulansari, 2019). To improve locomotor skills, it was necessary to support a learning environment which was conducive area to develop the children's potential (Rochcongar, 2014; Sutaryono, Irawan, et al., 2020), both in the indoor and outdoor environments.

Basically, children learn while playing, therefore learning in early childhood is basically playing. Some traditional games can be used as media to support children when playing the games. Traditional games were the media to make children more active in their activity as they did every day (Andriani, 2012; Setiawan, 2016). In accordance with the 
characteristics of children who are active in conducting various explorations of their environment. Children have to monitored by the teacher either parent every day to know their activities. Activities undertaken do not always rely on directions from parents or teachers. They can interact with friends or discover something new in the development of locomotor movements and activities (Hasiana, 2018; Sahanah \& Aprianti, 2018). The activities carried out at school are actually only a driving force in carrying out basic movements for children. The next stage is in the creativity of the child itself but still under the supervision of the teacher or parent. Experience in the field is knowledge and knowledge that is not obtained in school and it is expensive. Most children are too busy at home and are shackled by smartphones which make children have limitations in physical activities.

Based on observations of researchers at Madrasah Ibtidaiyah, researchers found that locomotor basic motion skills were still low and the lack of innovation in the delivery of the material provided such as the use of classrooms in learning and the field for physical activity. Children will feel comfortable and enjoy the lesson if the atmosphere in the classroom were fun. Increasing the achievement of child development at the age of 5-6 years i.e. Children can coordinate the movements in a controlled, balanced, and agile. Traditional games can be played in an outdoor place that can increase the enthusiasm of learning (Ma'azi Azizah, 2016). Traditional games were a means of enhancing the insights of knowledge gained from a series of play and adventure experiences that can stimulate one's spirit and physical activity (Anggita, 2019; Burhaein, 2017; Hapidin \& Yenina, 2016). The form of activities presented in the form of traditional games that were educational. Traditional game was essentially a game with coordination from the gestures and children were able to develop their kinesthetic abilities. Young children also have to protect their fundamental movement skills and habitual physical activity (Fisher et al., 2005) to increase physical performance.

Based on the existing problems, the researcher was interested in revealing the locomotor's ability to use traditional games for students at Madrasah Ibtidaiyah Lerep. The purpose of this study was to investigate the traditional games in the fundamental physical activities using locomotor skills.

\section{RESEARCH METHOD}

This study using Class Action Research (Arikunto, 2010) which aims to see how much the improvement in implementing traditional games. The study took place in Madrasah 
Ibtidaiyah Lerep Ungaran Barat and this study using boys 7-9 years old. This classification accordance with Kurniawan, (2018) and Tsapakidou, Stefanidou, \& Tsompanaki, (2014) which stated that age has an important role in the development of motion through analysis for the next stage. According to Irawan \& Permana, (2020); Sutaryono, Ansori, Irawan, \& Permana, (2020) with physical activity through traditional games, children will feel happy and even complacent they were indirectly doing physical activity through traditional games. This is the basis for recruiting the participants in this study using several criteria such as being active in physical activity, actively participating in school activities, and understanding some types of traditional games. This study already qualified from the review of Health Research Ethics Committee of Universitas Negeri Semarang, Indonesia based on the Standards and Operational Guidance for Human Participants regarding WHO 2011. 30 children participated in this study, and then they were homogenized in demographic characters such as social, economics, and live environment. After homogenized subjects, 20 subjects were randomly selected. In the last session, 18 participants were attending and participating traditional games in this study. All of the participants were agreed and full fill the inform consent and identity with the guidance from the teacher before did the games.

\section{Instrument}

The instrument test using Gross Motor Development edition 2 (EMGD-2) as Tsapakidou, Stefanidou, \& Tsompanaki, (2014) which is designed for children from 3-10 years. The test is divided into two sub-tests, a) in sub-test of travelling skills and b) in sub-test of handling skills. In the present study using method similar with Tsapakidou et al., (2014) study, only the sub-test of travelling was examined. This sub-test examined and assessed the correct implementation in: 1) running, 2) galloping, 3) hop scotching, 4) the jump stride, 5) the horizontal jump and 6) in the lateral run-gliding.

\section{Data Analysis}

Data collection in this study using observation sheet with data scoring techniques as follows: 
Table 1. Criteria of locomotor basic skills

\begin{tabular}{ccc}
\hline Number & Code & Category \\
\hline $\mathbf{8 2 - 1 0 0}$ & VW & Very Well Developed \\
$\mathbf{6 3 - 8 1}$ & DE & Develop as Expected \\
$\mathbf{4 4 - 6 2}$ & BD & Began to Develop \\
$\mathbf{2 5 - 4 3}$ & UD & Undeveloped \\
\hline
\end{tabular}

The category (table 1) divided into four types after modified as study needed, there were Very Well Developed, Develop as Expected, Began to Develop, and Undeveloped. According to Arikunto (2010), the criteria of locomotor basic skills were modified in accordance with the model and needed in this study. Based on the skills criteria set by the teacher, $75 \%$ children must get the grade in the Develop as Expectation category. This study also consisted of two cycles as Arikunto (2010), and each cycle divided into four steps, there were; planning, action, observation, and reflection.

\section{RESULT AND DISCUSSION}

\section{A. Result}

The results of this study found that at the first meeting participants were still unable to perform and enjoy traditional games correctly. Then they begin to adapt by understanding and adapting the game to their maximum performance as in the traditional games that children usually do. In this game, the locomotor motion they perform can be seen in the cycle 1 of locomotor basic skills (Figure 1).

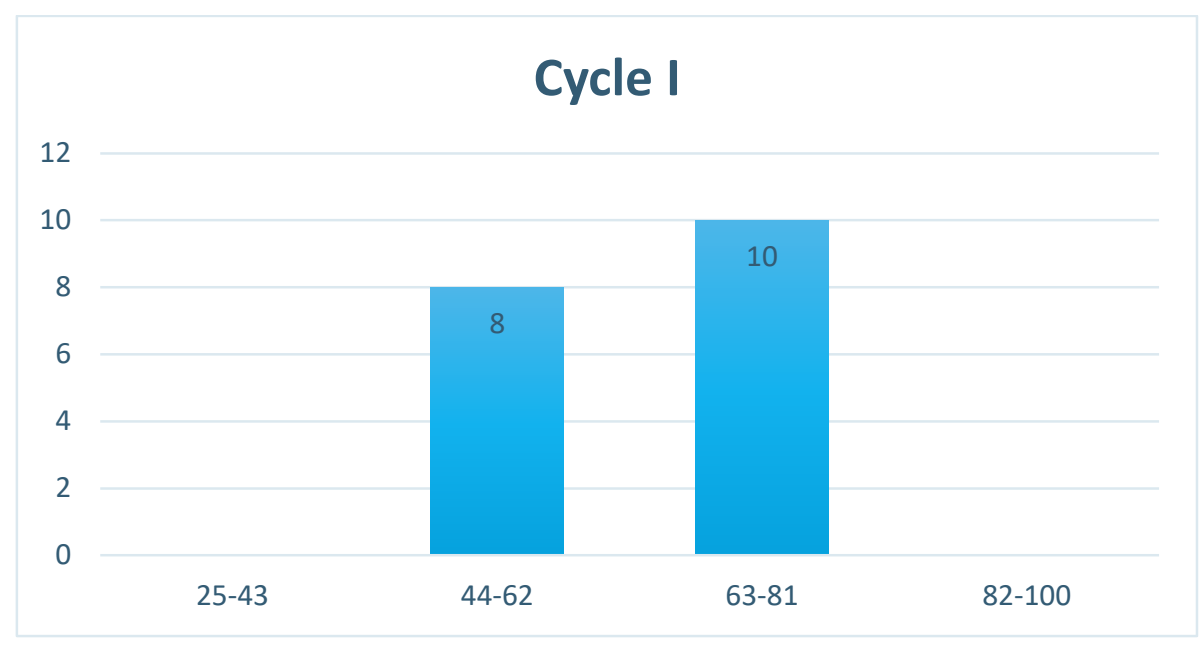

Figure 1. Cycle I of Locomotor Basic Skills 
There were only 8 children who got score 44-62 and 10 children who scored 63-81, so there were still some children who had not Developed as Expected (Figure 1). The influencing factors in the first cycle were the child has not concentrated on seeing examples of traditional games by the teacher. Some children still disturbing other friends and some other do not understand the rules of the game. Weaknesses that found in the first cycle become correction for improvement and were applied in the second cycle. In the second cycle, traditional games were used according to standard rules and have been agreed from the Indonesian Traditional People's Sports Games Committee (KPOTI). The games used includes Sunda Manda, Jumping Rope, Betengan, and Throwing Sandals. The instruments used were run, gallop, leap, jump, hop, kick, strike, dribble, and roll. In accordance with the implementation instructions conducted by Tsapakidou et al., (2014) in his study. In this second cycle, traditional games were more conducive because children already understand the rules of the game and children feel comfortable in practicing traditional games.

\section{B. Discussion}

Traditional games are a media to increasing students' physical activity. Traditional games in their application will be more educative by increasing social emotional abilities and providing positive meanings for students at school. This is inseparable from the intent and purpose of life-long learning which means that by playing students will learn a lot in everything. Through traditional games there are values and educational meanings in it. In addition, traditional games can also train students' emotions by training them to be more patient in waiting their turn while playing. In addition, students also indirectly learn to obey the rules (Apriliani et al., 2020; Setiawan, 2016; Yusria \& Musyaddad, 2019).

Through traditional games, students are immersed in the game so that they will avoid the burden of their thoughts and reduce the stress in their lives. In playing, students also feel free because their thoughts used in physical activities can divert their burdens and emotions for positive things (Yusria \& Musyaddad, 2019). This traditional game is also able to improve students' social emotional skills and increase their thinking power to be more creative and innovative. In playing traditional games, students are given an understanding of the rules and procedures for playing. It is hoped that students do it right. The activities and movements in this traditional game refer to the expected locomotor movements such as the steps that each student must do when they are young, starting from walking, running, jumping, and jumping. (Wijaya Kuswanto \& Dinda Pratiwi, 2020; Wulansari, 2019). 


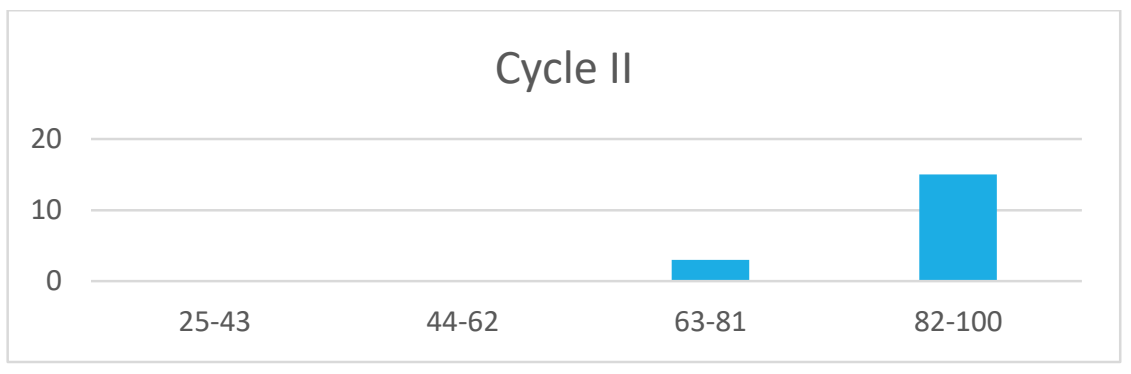

Figure 2. Cycle II of Locomotor Basic Skills

When some participant playing, another participant become supporters to encourage their friends to play, and vice versa. After the game was finished the children were given an evaluation and reward to motivate them to active in movement, as in the study Goodway, Crowe, \& Ward, (2003) and Wang, (2009). Locomotor basic skills at cycle II in Figure 2 can be seen that the children who Developed as Expected were 3 children and Very Well Developed as many as 15 children.

Activities which was implemented by children can increase stimulus motion and can develop motion skills to exquisite the children motoric skills. Study by Rismayanthi (2013) found that basic motion skills were motor stimulation for kindergarten children through physical education activities in the sports. She also recommended that children should do more activity for their growth and health. Irawan \& Permana, (2020); Permana \& Irawan, (2019) stated that traditional games were more attractive to give children activities. They are playing without any limit and have a deal as rules to playing the games. Natural movement (Irawan et al., 2020) will make children become active and elevate their performance in doing competition. Locomotor skills are the basic to improve achievement in the children especially who want to be an athlete.

Motor development is defined as the development of controlling bodily movements through coordinated activities of the nerve center, nerves and muscles. The ability of students both physically and motorically develops according to age and there are stages. The first stage develops normally. Second, its development has encountered a barrier. This causes the physical and motor development of children to tend to be predictable. Likewise, the growth of students as adults can grow normally or will be stunted (Indrawati \& Rahmah, 2020).

In coordinating student abilities, gross motor coordination skills in students are divided into three (Apriliani et al., 2020) . First, locomotor skills. Skills to move the body can be in the form of running, jumping, rolling, bouncing, walking, dropping, and sliding. These 
skills support awareness of motor perceptions. This awareness includes awareness of self, space, time, direction, and hearing. This can be seen when children try to imitate other people's movements.

This imitation movement is a basic motion that enters the memory and repeatedly resides in the nervous system and becomes automation. Second, non-locomotor skills. This skill includes the movement of the limbs of both the upper and lower extremities where the limb in question is only still, does not change position or does not move places. Movement in this skill is associated with balance in the body. The last skill is manipulation skill. This skill is an activity to control small muscle movements, with limited movements. Limited movement in this case is limited to the body parts of the hands and feet. Apart from manipulative motion, this third skill is also called the skill of projecting an object.

A person's skills are influenced by basic movements when they are children. This provision is what leads students to have skills in achievement. A student is also expected to grow and develop during the learning process both at home and at school. Good growth and development will support students' thinking skills and movement abilities, especially in activities. The golden age of students is not the same, but it can be predicted according to physical activity and ability to improve skills. Students who are active have an indication of improving their performance if they are supported by training programs and support from their closest people, including parents, coaches, friends, and family. As an effort to support these goals, educators and parents have an obligation to always accompany and monitor student growth and development and physical improvement, especially in locomotor motion. It is hoped that the basic movement will be carried out correctly to the next stage, namely towards improving performance.

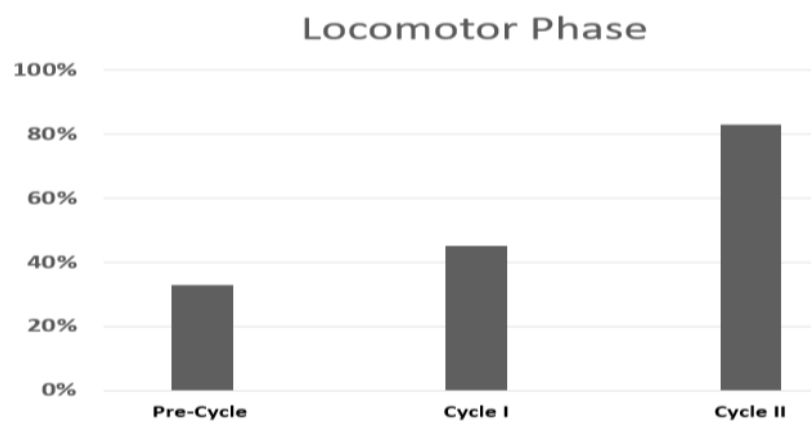

Figure 3. Comparison among pre-cycle, cycle I, and cycle II. 
Data collection from pre-cycle, cycle I, and cycle II were combined to find out how significant the differences among three data obtained. The difference can be seen in Figure 3 that there was significant difference. Explanation of the data among pre-cycle, cycle I, and cycle II where in the pre-cycle was $33 \%$ of participants in the Undeveloped category, then in the cycle I $45 \%$ of participants in Began to Develop, and in cycle II found $83 \%$ of participants received in Very Well-Developed.

Tsapakidou et al., (2014) investigated the locomotor development of fundamental movement skill learning among children 3.5 to 5 years of age. They found that children in their age have many potentials to increase fundamental basics skills for their future. Study from Rahajeng (2016) found that there were match between locator basic skill and manipulation skills for children more effective than a free-play program. The similar findings have been reported in other studies (Gallahue \& Donnelly, 2003; Okely et al., 2001). Relationship of physical activity to fundamental movement skill among adolescent provides children with a wealth of information to gives good perceptions of their growth.

Learning is an activity that involves a person in an effort to obtain knowledge, skills, recreations and positive values by utilizing various sources for learning and social communities. Learning can involve two parties, namely students as learners and teachers as facilitators and also sports management. For students, learning aims to bring changes in student behavior towards a better direction this can be addressed in various forms such as changes in knowledge, understanding attitudes and behavior and skills and other aspects that exist in individual students (Sutaryono, Ansori, et al., 2020). Locomotor skills cannot be reach with just one time, this ability is obtained by continuous training which is regular and increasing. Even though it has been done continuously, if a child does not do it in a certain period of time the movement may disappear from the memory.

Permana \& Irawan, (2019) also said that by doing physical activity through traditional games, the locomotor and locomotor movements are indirectly remembered and carried out automatically. this happens because the movement has entered the memory and the nerve response to the brain has received to be done at any time. This locomotor motion does not only rely on the ability of the muscles, but also links the work interactions of the brain. Balance and coordination of several physical components that are owned to make a person move flexibly. This balance can also be affected by the soles of the feet that are owned by each person. The model of the soles of the feet in a person has an effect even though Irawan et 
al., (2020) study did not find any significant differences. However, it affects the agility and speed of daily activities. Understanding and knowledge about learning motion must be emphasized in children to find out how children move normally without experiencing a problem and even injury in physical activity.

The creativity of teachers and parents is a source of information in providing learning about how to do locomotor motion properly and correctly. Direct practice in Physical Education at school also provides a special role in giving children experience how locomotor movements are done correctly. While playing at home with traditional games or folk games will indirectly increase children's physical activity and strengthen memory in carrying out movements that are difficult to do such as normal movements. These movements are like a series of running, jumping and rolling movements. The variation of these movements is a development of existing movements and is a combination of adjusting to the conditions in the field when playing. Non-locomotor, locomotor, and manipulative motion are a series of series that must be mastered by every child. If there is a series that is missed indirectly for children will experience difficulties when they grow up. The mismatch that is experienced, such as inadequate coordination when carrying out a movement, or also inadequate reaction speed in carrying out a movement. Before that happens, it would be best if every child should carry out each phase of the movement completely. In children phase they have stages in motor skills. starting on your back, then on your stomach, crawling, creeping, walking, running, and jumping.

Locomotor movements in traditional games have a huge impact. Some traditional games such as hadang, betengan, egrang, and suda manda (Irawan \& Permana, 2019), indirectly trigger the role of the brain in coordinating movements between several body components. Coordination between the eyes, hands and feet also affects the reaction speed a person has. It is also used for children with special needs in doing physical activities at school to improve fitness (Sutaryono, Irawan, et al., 2020). Traditional games have an important role in improving children's fitness and skills. In traditional games it takes physical, mental, and patient abilities. Traditional games also make a major contribution to how to learn and perform locomotor movements to the most difficult levels. Therefore, it takes people who have the patience and perseverance to accompany and direct the children, especially those who are learning locomotors and their variations. Teachers and parents are figures who have influence in mastering this locomotor motion. They are in accordance with the criteria to 
always accompany and improve the movements the children do both at home and at school. Physical education for all children gave a new knowledge for life experience and child development. This also applies to traditional games that can be used as a basis for learning locomotor motion in children. A limitation to this study was solely boys participating in this study, and this study only investigate the traditional games in the fundamental physical activities using locomotor skills.

\section{CONCLUSIONS AND SUGGESTIONS}

The result found that the data on the pre-cycle locomotor basic motion skills of $33 \%$ in the children's category Undeveloped. Cycle I found 45\% in the Began to Develop category and in the cycle II of $83 \%$ in the Very Well-Developed category. This study stated that traditional games was appropriate for a fundamental locomotor skill development. The weaknesses in this study that there were no data related to the children fitness condition. Future studies can add children's physical fitness activities that can monitoring the increase of physical abilities.

\section{REFERENCE}

Andriani, T. (2012). Permainan Tradisional Dalam Membentuk Karakter Anak Usia Dini. Jurnal Sosial Budaya, 9(1), 121-136. https://doi.org/http://dx.doi.org/10.24014/sb.v9i1.376

Anggita, G. M. (2019). Eksistensi Permainan Tradisional sebagai Warisan Budaya Bangsa. JOSSAE : Journal of Sport Science and Education, 3(2), 55. https://doi.org/10.26740/jossae.v3n2.p55-59

Apriliani, A. M., Yasbiati, Y., \& Elan, E. (2020). Meningkatkan Keterampilan Gerak Lokomotor Anak Usia 5-6 Tahun Di Kelas B Hijau Melalui Permainan Engklek Rintangan Di Tk Negeri Pembina Kota Tasikmalaya. Jurnal Paud Agapedia, 3(2), 178190. https://doi.org/10.17509/jpa.v3i2.26680

Arikunto, S. (2010). Prosedur Penelitian. Rineka Cipta.

Burhaein, E. (2017). Aktivitas Permainan Tradisional Berbasis Neurosainslearning Sebagai Pendidikan Karakter Bagi Anak Tunalaras. Jurnal SPORTIF : Jurnal Penelitian Pembelajaran, 3(1), 55. https://doi.org/10.29407/js_unpgri.v3i1.580

Fisher, A., Reilly, J. J., Kelly, L. A., Montgomery, C., Williamson, A., Paton, J. Y., \& Grant, S. (2005). Fundamental Movement Skills and Habitual Physical Activity in Young Children. Med Sci Sports Exerc, 37(4), 684-688.

Gallahue, D. L., \& Donnelly, F. C. (2003). Development Physical Education for All Children (4th ed.). HUMAN KINETICS PUBLISHERS, INC.

Goodway, J. D., Crowe, H., \& Ward, P. (2003). Effects of Motor Skill Instruction on Fundamental Motor Skill Development. Adapted Physical Activity Quarterly, 20(1), 298-314. 
Hapidin, \& Yenina. (2016). Pengembangan Model Permainan Tradisional Dalam Membangun Karakter Anak Usia Dini. JPUD - Jurnal Pendidikan Usia Dini, 10(2), 201-212. https://doi.org/10.21009/JPUD.102.01

Hasiana, I. (2018). mengembangkan karakter anak usia dini melalui permainan tradisional. Buana Pendidikan: Jurnal Fakultas Keguruan Dan Ilmu Pendidikan, 11(21). https://doi.org/10.36456/bp.vol11.no21.a1412

Indrawati, T., \& Rahmah, N. A. (2020). Peningkatan Kemampuan Motorik Kasar Anak Usia Dini Melalui Pembelajaran Gerak Tari Ayam. Al-Athfaal: Jurnal Ilmiah Pendidikan Anak Usia Dini, 3(1), 16-29. https://doi.org/10.24042/ajipaud.v3i1.6539

Irawan, F. A., Nurrahmad, L., \& Permana, D. F. W. (2020). The Association of Arch Height Index and Arcus Pedis on Agility: An Overview of Sport Science College Students. International Journal of Innovation, Creativity and Change, 14(11), 669-676.

Irawan, F. A., \& Permana, D. F. W. (2019). Permainan Rakyat Warisan Budaya Indonesia. In Buku Cetak (pp. 1-84). Fakultas Ilmu keolahragaan, Universitas Negeri Semarang.

Irawan, F. A., \& Permana, D. F. W. (2020). Parent-Child Fun Games sebagai Upaya Meminimalisasi Smartphone Addiction pada Anak di Madrasah Ibtidaiyah. Jurnal Pemberdayaan Masyarakat Mandiri Indonesia, 1(1), 1-8.

Kurniawan, R. (2018). Analisis Gerak Dasar Anak Usia 6-7 Tahun. Jurnal Pendidikan Anak Usia Dini, 12(2), 311-320.

Ma'azi Azizah, I. (2016). Efektivitas Pembelajaran Menggunakan Permainan Tradisional Terhadap Motivasi dan Hasil Belajar Materi Gaya Di Kelas IV MIN Ngronggot Nganjuk. Jurnal Dinamika Penelitian, 16(2). https://doi.org/10.21274/dinamika.2016.16.2.279-308

Okely, A. D., Booth, M. L., \& Patterson, J. W. (2001). Relationship of Physical Activity to Fundamental Movement Skill among Adolescents. Medicine \& Science in Sports \& Exercise, 33(11), 899-904.

Permana, D. F. W., \& Irawan, F. A. (2019). Persepsi Mahasiswa Ilmu Keolahragaan terhadap Permainan Tradisional dalam Menjaga Warisan Budaya Indonesia. Media Ilmu Keolahragaan Indonesia, 9(2), 50-53.

Rahajeng, O. W. (2016). Kesesuaian Keterampilan Gerak Lokomotor dan Keterampilan Manipulatif Anak Usia 4-5 Tahun Segugus II Kecamatan Galur. Jurnal Pendidikan Anak Usia Dini, 5(2), 171-181.

Rismayanthi, C. (2013). Mengembangkan Keterampilan Gerak Dasar Sebagai Stimulasi Motorik Bagi Anak Taman Kanak-Kanak Melalui Aktivitas Jasmani. Jurnal Pendidikan Jasmani Indonesia, 9(1), 64-72.

Rochcongar, P. (2014). Lesiones crónicas del aparato locomotor en el deportista. EMC Aparato Locomotor, 47(2), 1-10. https://doi.org/10.1016/S1286-935X(14)67557-2

Safrudin, A. (2017). Strategi Pembelajaran Aktif Anak Usia Dini. Kalimedia.

Sahanah, S., \& Aprianti, E. (2018). Upaya Guru Dalam Meningkatkan Kemampuan Gerak Lokomotor Melalui Permainan Tradisional Boi-Boian Pada Kelompok B Di TK Islam Rumah Ilmu Cimahi. CERIA (Cerdas Energik Responsif Inovatif Adaptif), 1(3), 24. https://doi.org/10.22460/ceria.v1i3.p24-29

Septi, W. A. D. (2015). Peningkatan Kemampuan Gerak Lokomotor Melalui Permainan Lari Estafet. Jurnal Pendidikan Usia Dini, 9(1), 163-180.

Setiawan, M. H. Y. (2016). Melatih Keterampilan Sosial Anak Usia Dini Melalui Permainan Tradisional. Jurnal Dimensi Pendidikan Dan Pembelajaran, 4(1), 1-8. https://doi.org/10.24269/dpp.v4i1.52 
Sutaryono, Ansori, I., Irawan, F. A., \& Permana, D. F. W. (2020). Development of Bakiak Football (Bakfoot) as Alternative Games for Elementary School. Development of Bakiak Football (Bakfoot) as Alternative Games for Elementary School - ICSS 2019, 10-14. https://doi.org/10.4108/eai.5-11-2019.2292524

Sutaryono, Irawan, F. A., \& Permana, D. F. W. (2020). Multicolor Flag game (MFG) as an Alternative Learning Method for Adaptive Students. Malaysian Journal of Movement, Health, 9(1), 187-193.

Tsapakidou, A., Stefanidou, S., \& Tsompanaki, E. (2014). Locomotor Development of Children Aged 3.5 to 5 years in Nursery Schools in Greece. Journal of Europian Studies, 6(2), 1-6.

Wang, J. H.-T. (2009). A Study on Gross Motor Skills of Preschool Children. Journal of Research in Childhood Education, 19(1), 32-43.

Wijaya Kuswanto, C., \& Dinda Pratiwi, D. (2020). Pengembangan Bahan Ajar Pendidikan Jasmani untuk Anak Usia Dini Berbasis Tematik. Al-Athfal : Jurnal Pendidikan Anak, 6(1), 55-68. https://doi.org/10.14421/al-athfal.2020.61-05

Wulansari, S. (2019). Meningkatkan Kemampuan Menerapkan Prosedur kombinasi Gerak Dasar Jalan, Lari, Lompat dan Lempar Dengan Permainan Olahraga Yang Dimodifikasi Dengan Olahraga Tradisional. Jurnal Ilmiah Pendidikan Agama Islam, 3(1), 77-92.

Yusria, \& Musyaddad, K. (2019). Permainan Tradisional Sebagai Model Permainan Edukatif Untuk Meningkatkan Kemampuan Sosial Emosional Anak Usia Dini. Al Athfaal: Jurnal Ilmiah Pendidikan Anak Usia Dini, 2(1), 14-24. 